\title{
Local Government Service Efficiency: Public Participation Matters
}

\author{
Zikri Muhammad, Tarmiji Masron, and Aziz Abdul Majid
}

\begin{abstract}
The service delivery efficiency by local authorities is one of the key elements in developing the livable cities. The involvement of local communities in measuring the efficiency of service delivery as a primary source of information should be practiced by all local authorities. However, local authorities are more likely to choose only some of the information given by the local community to improve the services delivery efficiency. This may be due to the low-level of involvement by local community for the dissemination of information to local authorities. This scenario will cause a conflict between local authorities and local communities. Local authorities should take into account the local communities view in measuring the service delivery efficiencies to create the livable cities. This study is important to assess the level of community involvement in sustainable urban development process. This study will identify the importance of community involvement in measuring the public service delivery. This study was conducted interviews among 360 respondents in Manjung and Kerian District in Perak. This study found that the level of involvement among the local communities in disseminating information to local authorities is still low.
\end{abstract}

Index Terms-Local authority, local participation, public governance, service delivery

\section{INTRODUCTION}

A good governance is based on the fully support by citizens in the implementation of national development programs. In general, most of citizen wants to get the high-level of service delivery efficiencies from the government, especially the basic services for life. Government should listen to the people views about the priority needs in service delivery performance. According to Malaysia Town and Country Planning Act 1976 (Act 172) and the amendment, public participation input must be taken into account in preparing the development plan such as Structure Plans, Local and Special Area Plan in Peninsular Malaysia. The public has a right to be notified and participate in any decision making that will affect their life. However, the government, especially the local authorities tend to disregard some opposite view of the development planned agenda. This situation contributes to the disorder in the local authority administrative system which may cause of low-level of service delivery efficiencies. Furthermore, the lack of monitoring on development programs will lead to financial problem.

However, customer management by the government is a very complicated. The government agency is a large

Manuscript received May 19, 2014; revised July 25, 2014.

The Authors are with the Universiti Sains Malaysia, Penang Malaysia (e-mail: zikri@usm.my,mmiji@usm.my, amaziz@usm.my ). organization that has a wide range of clients including citizens, business and employee communities, and employees of public or private sector [1]. Furthermore, one of the importance roles of government agencies is to provide information and services for each cluster of customers, especially citizens or local people [1]. Government agencies especially local government should aware that their services delivery will be evaluated by the citizens. This scenario will affect on the public assessment at a general election to vote the party that will lead the country. The low-level of knowledge and skills of public sector employees and inefficient operating systems will contribute to customer dissatisfaction. Customer satisfaction is one of the factors that contribute to the quality of the goods or services delivered [2] and considered one of the indicators for public service performance measurements [3]. Besides that, customer satisfaction measurement is used to improve the quality of goods or services that will contribute to the competitive advantage of the organization [4].

The inefficiencies urban management can contribute to the failure of development projects and low performance of service delivery by local authorities. This scenario occurs when local authorities fail to meet the expectations of their customers [5]. This argument supports by Freemantle study which pointed out that the main reason of complaints by customers is the failure to perform the promise, incompetence, delay, failed to inform about the changes and the lack of flexibility in a direction [6]. Meanwhile, study by Parasuraman et al. explained that there was a gap in service delivery processes between suppliers and users. The gap exists is due to the services provided by the supplier cannot meet the requirements of the buyer or user [7]. This is supported by Davison and Grieves which concluded that there is a significant gap between the expectations of the manager of an organization with customer expectations [8]. For managers, quality assessment based on the right services, reliable and fair, competitive staff, and well-mannered. However, the customers will evaluate the quality of service, based on positive image, the range of services offered, the right time to react, good communication with customers and compliance with contract specifications. Besides that the implementation of e-government program especially e-complaint for the residents can improve the government operation internally as well as the quality of service delivery [9], [10]. The local government can manage the performance management measurement especially the service delivery performance by providing the infrastructure for performance management [11]. However, the local government needs a good planning system to enhance efficiency and effectiveness and to offer improved services for sustainable development [12]. 


\section{METHOD}

\section{A. The Unit of Analysis and Population}

The unit of analysis in this study are the residents of Manjung and Kerian Town. They include low cost and medium cost housing. The population is being studied involves 10,000 residents.

\section{B. Questionnaire Administration}

Data was collected through a structured questionnaire, for each housing unit selected. The principal investigator met the residents at their home during working hours and weekend. Each resident will be given a questionnaire attached with a covering letter guaranteeing confidentiality and informed consent for the research. Respondents filled in the questionnaire anonymously. The principal investigator then collected the questionnaires either on the same day or two weeks later. For those who were unable to complete the questionnaire, assistance was given or an interview made by the principal investigator. Onsite editing of the questionnaires was made and checked twice at the university. The population was first stratified to location and type of development in order to get the various sub-groups of the population. The technique of sampling used in this study basically the convenience sampling, but taking into account housing location and the different types of development. This will ensure that the various subgroups in the population are represented. A total of 370 questionnaires were distributed and only 360 were usable. As such, the usable response rate is 97.30 percent.

\section{RESULT}

\section{A. Profile of the Residents}

There were 70.2 percent males and 29.8 percent females. With regards to marital status, 80.2 percent of the residents were married, 9.8 percent were single, and 10 percent were divorced. They were predominantly Malay (70.2\%), followed by Chinese (18\%), Indian (10\%), and others (1.8\%). More than half $(60 \%)$ of the residents belonged to young age group from 19 to 45 years old. About 74 percent had education below or equal to college diploma level. The large majority $(81.7 \%)$ had an income of less than RM5,000 per month. A total of 177 (49.2\%) respondents were from the low cost housing while $183(50.8 \%)$ were from the medium cost housing.

\section{B. Testing the Goodness of Measure for the Service Delivery of Local Authority Construct}

\section{1) Content validity}

Content validity refers to the extent to which an instrument covers the meanings included in the concept [13]. Researchers, rather than by statistical testing, subjectively judge content validity [14]. The content validity of the proposed instrument is at least sufficient because the instrument is carefully refined from a proven instrument with an exhaustive literature review [14].

\section{2) Construct validity}

Based on the rotated component matrix, out of 40 items, eight items were dropped as they either had loadings less than 0.5 or cross loadings. Seven factors met the selection criteria of eigenvalues greater than 1.0, explaining a total of 70.21 percent of the variance. The KMO measure of sampling adequacy was 0.78 indicating sufficient intercorrelations while the Bartlett's Test of Sphericity was significant $\left(\chi^{2}=\right.$ 13241.23, $p<0.01)$. All the items selected had factor loadings greater than 0.5 . Factor 1 contained eight items and has been labelled as "Complaining Services". In Factor 2, five items were included and then labelled as "Community Development Services". Five items loaded onto Factor 3 and named as "Law Enforcement Services". Factor 4 consisted of four items and thus was labelled as "Environmental Management Services". Factor 5 included four items and represent as "Basic Amenities Services". Finally, Factor 6 and 7 only included three items for each factor and this has been labelled as "Community Health Services" and "Street and Light Services". Table I presents the factor loadings obtained.

\section{3) Convergent validity}

According to Campbell and Fiske, convergent validity refers to all items measuring a construct actually loading on a single construct [15]. Convergent validity is established when items all fall into one factor as theorized. All seven factors displayed unidimensionality with Complaining Services, $\mathrm{KMO}=0.86$ explaining 68.34 percent of the variation; Community Development Services, $\mathrm{KMO}=0.86$ explaining 72.51 percent of the variation; Law Enforcement Services, KMO $=0.84$ explaining 76.45 percent of the variation; Environmental Management Services, KMO = 0.84 explaining 72.86 percent of the variation; Basic Amenities Services, $\mathrm{KMO}=0.82$ explaining 69.42 percent of the variation; Community Health Services, $\mathrm{KMO}=0.76$ explaining 75.86 percent of the variation; and lastly Street and Light Services, KMO = 0.68 explaining 61.48 percent of the variation. Thus, it can be concluded that the convergent validity of these measures is valid.

\section{4) Discriminant validity}

A correlation analysis was done on the seven factors generated and the results are presented in Table II. As can be seen all seven factors are not perfectly correlated where their correlation coefficients range between 0 and 1 . Hence, this study can be concluded that discriminant validity has been established.

\section{5) Reliability}

According to Nunnally alpha values equal to or greater than 0.70 can be considered a sufficient condition [16]. This study used Cronbach alpha value for testing the inter-item consistency. The seven corresponding alpha values are 0.92 , 0.93, 0.91, 0.89, 0.83, 0.82, and 0.70 for Complaining Services, Community Development Services, Law Enforcement Services, Environmental Management Services, Basic Amenities Services, Community Health Services and Street and Light Services respectively (Refer Table II). This study concluded that these measures possess sufficient reliability. 
TABLE I: FACTOR ANALYSIS RESULT FOR SERVICE DELIVERY.

\begin{tabular}{|c|c|c|c|c|c|c|c|}
\hline \multirow{2}{*}{ Items } & \multicolumn{7}{|c|}{ Factors } \\
\hline & F1 & F2 & F3 & F4 & F5 & F6 & F7 \\
\hline \multicolumn{8}{|c|}{ Factor 1: Complaining Services } \\
\hline CS1 & 0.75 & & & & & & \\
\hline $\mathrm{CS} 2$ & 0.83 & & & & & & \\
\hline $\mathrm{CS} 4$ & 0.75 & & & & & & \\
\hline CS5 & 0.79 & & & & & & \\
\hline CS6 & 0.77 & & & & & & \\
\hline $\mathrm{CS} 7$ & 0.86 & & & & & & \\
\hline CS9 & 0.87 & & & & & & \\
\hline CS10 & 0.77 & & & & & & \\
\hline
\end{tabular}

Factor 2: Community Development Services

\begin{tabular}{ll}
\hline CDS1 & 0.71 \\
CDS2 & 0.79 \\
CDS3 & 0.85 \\
CDS4 & 0.75 \\
CDS5 & 0.88 \\
\hline
\end{tabular}

\begin{tabular}{lc}
\hline Factor 3: Law Enforcement Services & \\
\hline LES1 & 0.77 \\
LES2 & 0.85 \\
LES3 & 0.89 \\
LES4 & 0.82 \\
LES5 & 0.81 \\
\hline
\end{tabular}

Factor 4: Environmental Management Services

\begin{tabular}{lc}
\hline EMS2 & 0.71 \\
EMS3 & 0.87 \\
EMS4 & 0.89 \\
EMS5 & 0.81 \\
\hline Factor 5: Basic Amenities Services & 0.80 \\
BAS1 & 0.85 \\
BAS2 & 0.89 \\
BAS3 & 0.86 \\
BAS4 & 0 \\
\hline
\end{tabular}

\section{Factor 6: Community Health Services}

\begin{tabular}{lll} 
CHS1 & 0.72 \\
CHS2 & 0.79 \\
CHS3 & 0.77 \\
\hline
\end{tabular}

\section{Factor 7: Street and Light Services}

\begin{tabular}{|c|c|c|c|c|c|c|c|}
\hline SLS3 & & & & & & & 0.77 \\
\hline SLS4 & & & & & & & 0.62 \\
\hline SLS5 & & & & & & & 0.77 \\
\hline Eigenvalue & 10.72 & 6.61 & 2.12 & 1.77 & 1.52 & 1.33 & 1.12 \\
\hline Percentage of Variance & 23.11 & 12.23 & 10.11 & 9.75 & 8.58 & 7.12 & 5.55 \\
\hline Total Variance Explained & 22.22 & 35.44 & 45.77 & 54.86 & 64.76 & 69.33 & 74.86 \\
\hline KMO Measure of Sampling Adequacy & & & & 0.78 & & & \\
\hline Approximate Chi-Square & & & & $1.23^{*}$ & & & \\
\hline
\end{tabular}

Note. $N=360$. Items included for the respective factors are underlined for identification; $* * * P<.001$. Factor loadings less than .30 have not been printed. 
TABLE II: RESULTS OF THE CORRELATION ANALYSIS

\begin{tabular}{|c|c|c|c|c|c|c|c|c|}
\hline \multicolumn{2}{|c|}{ Item } & 1 & 2 & 3 & 4 & 5 & 6 & 7 \\
\hline 1 & Complaining Services & $(0.92)$ & & & & & & \\
\hline 2 & Community Development Services & $.61 * *$ & $(0.93)$ & & & & & \\
\hline 3 & Law Enforcement Services & $.41 * *$ & $.55^{* *}$ & $(0.91)$ & & & & \\
\hline 4 & Environmental Management Services & $.25 * *$ & $.19 * *$ & $.26^{* *}$ & $(0.89)$ & & & \\
\hline 5 & Basic Amenities Services & .11 & $.16^{* *}$ & $.32 * *$ & $.55^{* *} *$ & $(0.83)$ & & \\
\hline 6 & Community Health Services & $.23 * *$ & $.42 * *$ & $.42 * *$ & $.38 * *$ & $.47 * *$ & $(0.82)$ & \\
\hline 7 & Street and Light Services & $.19 * *$ & $.28 * *$ & $.32 * *$ & $.47 * *$ & $.45^{* *}$ & $.43^{* *}$ & $(0.70)$ \\
\hline
\end{tabular}

Note: Values in the diagonal are Cronbach alpha coefficients.

\section{6) The level of service delivery efficiency}

In general, this study found that the level of service delivery efficiency by local authorities from customer perspective in Manjung and Kerian town are at a high level for complaining services, community services, and environmental management services. However, the community development program and law enforcement services are at moderate level. More than 50 percent of respondents agreed that all the services above need to be improved in the future. Meanwhile, more than 50 percent of the respondents concluded that the basic services and street and light services provided by local authority are at low-level Local authority need to pay more attention on basic amenities services such as waste management, street maintenance, drainage, river management and cleaning of public area. Besides that, local authority must be monitored all aspects of maintenance regarding to light and street services. It can be concluded that, the level of service delivery efficiency by both local authority in Manjung and Kerian must be improved in the future based on the need of local people.

\section{7) The level of public participation}

The study found that the level of public participation in planning and improving services delivery efficiency process still at low levels. More than 61 percent of respondents stated that they were not involved in any plans or improvements in service delivery by local authority. Besides that, more than 53 respondents are not aware about the right to contribute ideas in the planning, improving or development programs provided by local authorities. This study also found that less than $35 \%$ involves in public hearing for Local Area Plan. However, Most of respondents doubted that their views will use in preparing Local Plan Development program. Besides that, 45 percent of the respondents are willing to contribute their ideas in improving the service delivery efficiencies by local authority.

\section{DISCUSSION}

The idea of public participation is based on the democratic system to protect the rights of individuals and the public interest. Public participation is seen as important elements of the democratic government. Public participation in the development program and improvement of service delivery has been suggested as an effective way to achieve sustainable development and brings a lot of positive impact on society. According to the Act, there are opportunities and right of the public to know the plan in their area and have opportunity to make objections, but there are some problems, criticism and dilemmas of public participation in the government plan which cause execution on development program not successful. However, the public's understanding on participation concept is still confused. So, this is impossible for them to involve in public participation programs such as Local Plan public hearing program on Local Plan designed by Local Authority. Meanwhile, most of the participant are the ones who have their own interests, such as developers or those who are involved in the planning. Local government should take a good opportunity to improve their services form perspective of customer's views point. This study has proven that some of the customers are willing to contribute their idea and suggestions based on their local knowledge to improve the services delivery.

\section{ACKNOWLEDGEMENTS}

This research is funded by Short Term Grant Universiti Sains Malaysia (USM). 304/PHUMANITI/6313003

\section{REFERENCES}

[1] S. Chen, B. Mulgrew, and P. M. Grant, "A clustering technique for digital communications channel equalization using radial basis function networks," IEEE Trans. on Neural Networks, vol. 4, pp. 570-578, July 1993.

[2] A. M. Zamil and M. M. Shammot, "Role of measuring customer satisfaction in improving the performance in the public sector organization," J. Bus. Stud. Quar, vol. 2, no. 3, pp. 32-42, 2011.

[3] T. G. Vavra, Improving your Measurement of Customer Satisfaction: A Guide to Creatin, ASQ Quality Press, Milwaukee, WI, 1997, pp. 430-440.

[4] G. A. Boyne, "Concepts and indicators of local authority performance: an evaluation of the statutory frameworks in England and Wales," Pub, Mon, Man, vol. 22 no. 2, pp. 17-24, 2002.

[5] D. W. Cravens, C. W. Holland, C. W. Lamb, and W. C. Moncrief, "Marketing's role in product and service quality," Industrial Marketing Management, vol. 17, pp. 285-304, 1998.

[6] C. Brennan and A. Douglas, "Complaints procedures in local government: informing your customer," The International Journal of Public Sector Management, vol. 15, no. 3, pp. 219-236, 2002.

[7] D. Freemantle, What Customers Like About you Adding Emotional Value for Service Excellence and Competitive Advantage, London: Nicholas Brealey Publishing, 1998.

[8] A. Parasuraman, V. A. Zeithaml, and L. L. Berry, "A conceptual model of service quality and its implications for future research," Journal of Marketing, vol. 49, pp. 41-50, 1985.

[9] J. Davison and J. Grieves, "Why should local government show an interest in service quality," The TQM Magazine, vol. 8, no. 5, pp. 32-38, 1996

[10] A. A. Rashid, H. Jusoh, and J. A. Malek, "Enhancing urban governance efficiency through the egovernment of Malaysian local authorities The case of Subang Jaya," GEOGRAFIA Online TM Malaysian Journal of Society and Space, vol. 6, issue. 1, pp. 1-12, 1996.

[11] R. M. Ramli, "Malaysian e-government: issues and challenges in public administration," IPEDR, vol. 48, pp. 19-23, 2012.

[12] Rivenbark, W. C. Roenigk, D. J. Noto, and Lidia, "Navigating efficiency and effectiveness relationship across local government services: Another step toward strategic resource management," Journal 
of Public Budgeting, Accounting and Financial Management, vol. 25 , issue. 4, pp. 675-692, Winter 2013.

[13] N. Khilji and S. Roberts, "An exploratory study of knowledge management in the UK local government planning system for improved efficiency and effectiveness," in Proc. the International Conference on Intellectual Capital, Knowledge Management \& Organizational Learning, 2013, pp. 551-560.

[14] E. Babbie, The Practice of Social Research, Wadsworst: Belmont, CA 1992.

[15] W. S. Chow and K. H. Lui, "Discriminating factors of information systems function performance in Hong Kong firms practicing TQM,' International Journal of Operations and Production Management, vol. 21 , no. $5 / 6$, pp. 749-771, 2001.

[16] D. T. Campbell and D. W. Fiske, "Convergent and discriminan validation by the multitrait-multimethod matrix," Psychological Bulletin, vol. 56, no. 1, pp. 81-105, 1959.

[17] J. C. Nunnally, Psychometric Theory, McGraw Hill: New York, 1978.

Zikri Muhammad was born in Terengganu, Malaysia in 1977. He received the bachelor degree in business administrative from the University Putra Malaysia in 1999, master of art (urban and regional planning) from Universiti Sains Malaysia in 2005 and the Ph.D. degrees in urban geography from Universiti Kebangsaan Malaysia in 2012. In 2012, he joined the Department of Geography, University Sains Malaysia, as a senior lecturer, His current research interests include local government, urban geography, regional planning and industrial planning.

Tarmiji Masron was born in Sarawak and he is a professor in geographical information system (GIS) in the Section of Geography, School of Humanities, Universiti Sains Malaysia. He received his $\mathrm{PhD}$ in geographic information system (GIS) from Universiti Sains Malaysia and has field expertise in GIS, spatial social science, spatial tourism and spatial decision support system (SDSS). He is heavily involved in research work, publications and consultations related to geographic information systems (GIS) in the social sciences, local knowledge, tourism and SDSS.

Aziz Abdul Majid was born in Pahang, Malaysia in 1958. He received the bachelor degree in Agronomy from Iowa State University 1983 and master of science in agriculture from Sam Houston State University in 1984. He joined the Department of Geography in 1989, University Sains Malaysia, and now he is a senior lecturer 